Folia Cardiologica 2015 tom 10 , nr 1 , strony 58-64 DOI: 10.5603/FC.2015.0010 Copyright @ 2015 Via Medica ISSN 2353-7752

\title{
Diagnostyka kardiomiopatii takotsubo
}

\author{
Diagnosis of takotsubo cardiomyopathy
}

\author{
Monika Budnik, Gabriela Parol \\ I Katedra i Klinika Kardiologii Warszawskiego Uniwersytetu Medycznego
}

\section{Streszczenie}

Kardiomopatia takotsubo (TCM) jest stosunkowo niedawno opisaną jednostką chorobową, której objawy przypominają ostry zespół wieńcowy. Występuje u 1-3\% pacjentów zgłaszających się do szpitala z powodu podejrzenia zawału serca. Etiologii choroby nie ustalono. Rokowanie u osób z TCM jest dobre - w ciągu kilku tygodni dochodzi do poprawy funkcji skurczowej lewej komory, jednak czasami występują powikłania, które mogą być śmiertelne. Jak najwcześniejsze odróżnienie od zawału serca jest niezwykle istotne, gdyż choć objawy kliniczne są bardzo podobne, to leczenie i rokowanie pozostają odmienne. Dlatego liczni badacze na całym świecie próbują opracować kryteria, na podstawie których można by odróżnić te dwie jednostki chorobowe już na początku wystąpienia objawów.

Słowa kluczowe: takotsubo, zespół balotującego koniuszka, kardiomiopatia stresowa

(Folia Cardiologica 2015; 10, 1: 58-64)

\begin{abstract}
Wstęp
Kardiomiopatia takotsubo (TCM, takotsubo cardiomyopathy), nazywana również zespołem balotującego koniuszka lub kardiomiopatią stresową, jest najczęściej definiowana jako nagła i w większości przypadków odwracalna dysfunkcja skurczowa lewej komory (LV, left ventricle), której objawy przypominają ostry zespół wieńcowy (ACS, acute coronary syndrome), bez współistniejących zmian w tętnicach wieńcowych [1, 2]. Po raz pierwszy terminu „kardiomiopatia takotsubo" użyto w 1990 roku. Nazwa pochodzi od spostrzeżenia, że szczególny kształt LV w okresie późnoskurczowym, obserwowany w trakcie wykonywania wentrykulografii, przypomina takotsubo, czyli naczynie o okrągłym dnie i wąskiej szyi stosowane w przeszłości w Japonii do połowu ośmiornic [3]. Większość pacjentów to kobiety po menopauzie, z bólem w klatce piersiowej, podwyższonym stężeniem markerów martwicy miokardium oraz zmianami niedokrwiennymi w zapisie elektrokardiograficznym (EKG), które zazwyczaj poprzedza stres emocjonalny lub fizyczny [4]. Liczni autorzy próbują opracować kryteria diagnostycz-
\end{abstract}

ne TCM, które umożliwiłyby odróżnienie jej od ACS już na początku wystąpienia objawów klinicznych.

\section{Kryteria diagnostyczne}

Najczęściej stosowane kryteria rozpoznawania TCM to kryteria Mayo Clinic (tab. 1) [4]. Wydają się one jednak coraz mniej aktualne ze względu na pojawiające się liczne publikacje opisów przypadków TCM u pacjentów, u których według tych założeń są spełnione kryteria wykluczające. Jednym z takich kryteriów jest „obecność istotnych zmian w tętnicach wieńcowych". Istnieją opisy przypadków TCM u pacjentów po przebyciu zawału serca lub z angiograficznymi zwężeniami w tętnicach wieńcowych. Podobnie jako kryterium wykluczające autorzy wymieniają obecność pheochromocytoma. W piśmiennictwie są opisywane przypadki pacjentów z guzem chromochłonnym, u których również rozpoznano TCM. W 2007 roku Japońskie Towarzystwo Kardiologiczne opracowało własne kryteria rozpoznawania TCM (tab. 2) [5]. Obejmują one jedynie typową formę tej kardiomiopatii, tj. dotyczącą segmentów koniuszkowych LV. 
Tabela 1. Kryteria rozpoznawania kardiomiopatii takotsubo według Mayo Clinic (na podstawie [4])

Przemijające zaburzenia kurczliwości segmentów środkowych lewej komory w postaci hipokinezy, akinezy lub dyskinezy, z zajęciem lub nie segmentów koniuszkowych; odcinkowe zaburzenia kurczliwości wykraczające poza obszar unaczynienia pojedynczej tętnicy wieńcowej; częsty, ale nie zawsze obecny czynnik stresowy

Brak zwężeń w tętnicach wieńcowych lub angiograficznych dowodów pęknięcia blaszki miażdżycowej

Nowe zmiany w zapisie elektrokardiograficznym (uniesienie odcinka ST i/lub odwrócenie załamka T) lub niewielki wzrost stężenia troponiny

Wykluczenie pheochromocytoma i zapalenia mięśnia sercowego

Pozostałe typy, takie jak odwrócone czy dotyczące segmentów środkowych, w ogóle nie zostały uwzględnione w klasyfikacji. Brak istotnego zwężenia w tętnicach wieńcowych jest warunkiem niezbędnym do postawienia diagnozy. Zaburzenia kurczliwości, takie jak w klasycznej formie TCM, które mogą towarzyszyć incydentom mózgowo-naczyniowym, określono jako „choroby krążenia mózgowego z dysfunkcją mięśnia sercowego podobną do kardiomiopatii takotsubo (cerebrovascular disease with takotsubo-like myocardial dysfunction) i odróżniono od idiopatycznej TCM. Schorzeniami, które muszą zostać wykluczone przed postawieniem diagnozy TCM, są ACS, choroby mózgowo-naczyniowe, pheochromocytoma i zapalenie mięśnia sercowego. Ta klasyfikacja również wydaje się niedoskonała, głównie ze względu na restrykcyjne kryteria wykluczające oraz nieuwzględnienie atypowych form TCM dotyczących innych regionów LV niż segmenty koniuszkowe.

Kryteria Johns Hopkins dzielą się na kryteria „pomocne, ale niekonieczne”, które obejmują: znany emocjonalny lub fizyczny czynnik wywołujący objawy, zmiany w EKG, wzrost stężenia markerów sercowych mających związek z TCM oraz „kryteria obowiązkowe”, do których należą: brak skrzepliny lub angiograficznych dowodów pęknięcia blaszki miażdżycowej, odcinkowe zaburzenia kurczliwości wykraczające poza obszar unaczynienia pojedynczej tętnicy wieńcowej, całkowite ustąpienie zaburzeń kurczliwości. Wszystkie trzy kryteria obowiązkowe muszą być spełnione (tab. 3)

Tabela 2. Kryteria rozpoznawania kardiomiopatii takotsubo (TCM, takotsubo cardiomyopathy) według Japońskiego Towarzystwa Kardiologicznego (na podstawie [5])

\section{Definicja}

Kardiomiopatia takotsubo jest chorobą polegającą na balotowaniu koniuszka LV o nieznanej przyczynie

Lewa komora przyjmuje kształt takotsubo (japońskiego narzędzia do łapania ośmiornic). W większości przypadków w ciągu miesiąca dochodzi do niemal całkowitego ustąpienia zaburzeń kurczliwości w obrębie koniuszka. Zaburzenia te zazwyczaj dotyczą LV, ale zajęcie prawej komory również jest obserwowane w niektórych przypadkach. Obserwuje się także dynamiczne zawężanie drogi odpływu LV Uwaga: Istnieje grupa pacjentów, np. po incydentach naczyniowo-mózgowych, u których dochodzi do balotowania koniuszka LV podobnego do TCM, ale o znanej przyczynie. U takich pacjentów diagnozuje się chorobę układu naczyniowo-mózgowego z dysfunkcją mięśnia sercowego podobną do TCM i odróżnia od przypadków idiopatycznych

\section{Kryteria wykluczające}

Istotne zwężenie lub skurcz naczyń wieńcowych, szczególnie ostry zawał serca spowodowany zamknięciem gałęzi przedniej zstępującej, która zaopatruje obszar obejmujący koniuszek LV (wykonanie koronarografii jest wskazane w ostrej fazie, ale także w fazie przewlekłej w celu potwierdzenia lub wykluczenia istotnych zmian mogących powodować zaburzenia kurczliwości)

Choroby układu naczyniowo-mózgowego

Guz chromochłonny

Wirusowe lub idiopatyczne zapalenie mięśnia sercowego

\section{Diagnostyka}

Objawy: ból w klatce piersiowej i duszność podobne do występujących w ostrym zespole wieńcowym; TCM może przebiegać bez objawów Czynniki wyzwalające: stres emocjonalny lub fizyczny może wywoływać TCM, ale może ona wystąpić także bez żadnego czynnika wyzwalającego

Różnice wieku i płci: znana tendencja do wzrostu częstości w starszym wieku, szczególnie u kobiet

Morfologia LV: balotowanie koniuszka z szybką poprawą w wentrykulografii i echokardiografii

Zapis ECG: na początku objawów może być obserwowane uniesienie odcinka ST, następnie - w typowych przypadkach - załamek T staje się coraz bardziej ujemny w wielu odprowadzeniach, a odstęp QT jest wydłużony. Zmiany te stopniowo ustępują, ale ujemne załamki T mogą utrzymywać się przez kilka miesięcy. W ostrej fazie mogą być obserwowane patologiczne załamki Q i zmiany woltażu QRS Biomarkery sercowe: w typowych przypadkach dochodzi do niewielkiego wzrostu stężeń markerów sercowych i troponiny Badania nuklearne: w niektórych przypadkach nieprawidłowe wyniki scyntygrafii mięśnia sercowego

Rokowanie: w większości przypadków dochodzi do szybkiej poprawy, ale u niektórych pacjentów może wystąpić obrzęk płuc lub inne następstwa, a nawet może dojść do zgonu 
Tabela 3. Kryteria rozpoznawania kardiomiopatii takotsubo według Johns Hopkins (na podstawie [6])

Kryteria pomocne, ale nieobowiązkowe

Nagły czynnik wyzwalający (emocjonalny lub fizyczny)

Charakterystyczne zmiany w EKG, które mogą obejmować niektóre lub wszystkie spośród następujących:

- uniesienie odcinka ST przy przyjęciu (często $\leq 2 \mathrm{~mm}$ i zwykle niezwiązane z przeciwstawnym obniżeniem odcinka ST) - rozlane, głębokie odwrócenie załamka T (może być obecne przy przyjęciu lub ewoluować w czasie kilku dni hospitalizacji) - wydłużenie odstępu QT (zwykle maks. przez 24-48 h)

Nieznacznie podwyższone stężenie troponiny (często nieproporcjonalnie niskie w stosunku do stopnia nasilenia zaburzeń kurczliwości)

Kryteria obowiązkowe (wszystkie trzy kryteria muszą być spełnione)

Brak skrzepliny lub angiograficznych dowodów pęknięcia blaszki miażdżycowej w tętnicach wieńcowych

Odcinkowe zaburzenia kurczliwości wykraczające poza obszar zaopatrywany przez pojedynczą tętnicę wieńcową

Całkowite ustąpienie odcinkowych zaburzeń kurczliwości (zwykle w ciągu dni lub tygodni)

Tabela 4. Kryteria diagnostyki kardiomiopatii takotsubo według Gothenburg (na podstawie [7])

Przemijająca hipokineza, akineza lub dyskineza segmentów lewej komory, często ale nie zawsze poprzedzona stresującym wydarzeniem (fizycznym lub emocjonalnym)

Wykluczenie innych patologii (m.in. niedokrwienia, zapalenia mięśnia sercowego, toksycznego uszkodzenia, tachykardii), które mogą bardziej wiarygodnie wyjaśniać zaburzenia kurczliwości

Prawidłowe lub prawie prawidłowe ciśnienie napełniania

[6]. Kryteria te są uzasadnione, jednak nie uwzględniono w nich możliwości współwystępowania TCM i ACS, co już opisano w piśmiennictwie.

Kolejnymi kryteriami stosowanymi w diagnostyce TCM są kryteria Gothenburg [7]. Ich autorzy odnoszą się do powodów niedoszacowania częstości występowania TCM. Należą do nich wykluczenie możliwości współwystępowania z chorobą wieńcową i guzem chromochłonnym oraz nieuwzględnienie pacjentów, którzy zmarli (tab. 4) [7]. Mimo że odnoszą się tylko do pacjentów, którzy przeżyli ostrą fazę TCM, to autorzy zwracają uwagę na konieczność opracowania dodatkowych histologicznych kryteriów, które będą mogły znaleźć zastosowanie u zmarłych chorych. Madias w 2014 roku [8] zaproponował nowe kryteria rozpoznawania TCM uwzględniające możliwość współwystępowania z innymi chorobami, które mogą stanowić zarówno czynnik wyzwalający TCM, jak i być jej wynikiem. Dane z badania echokardiograficznego przeprowadzonego bezpośrednio po
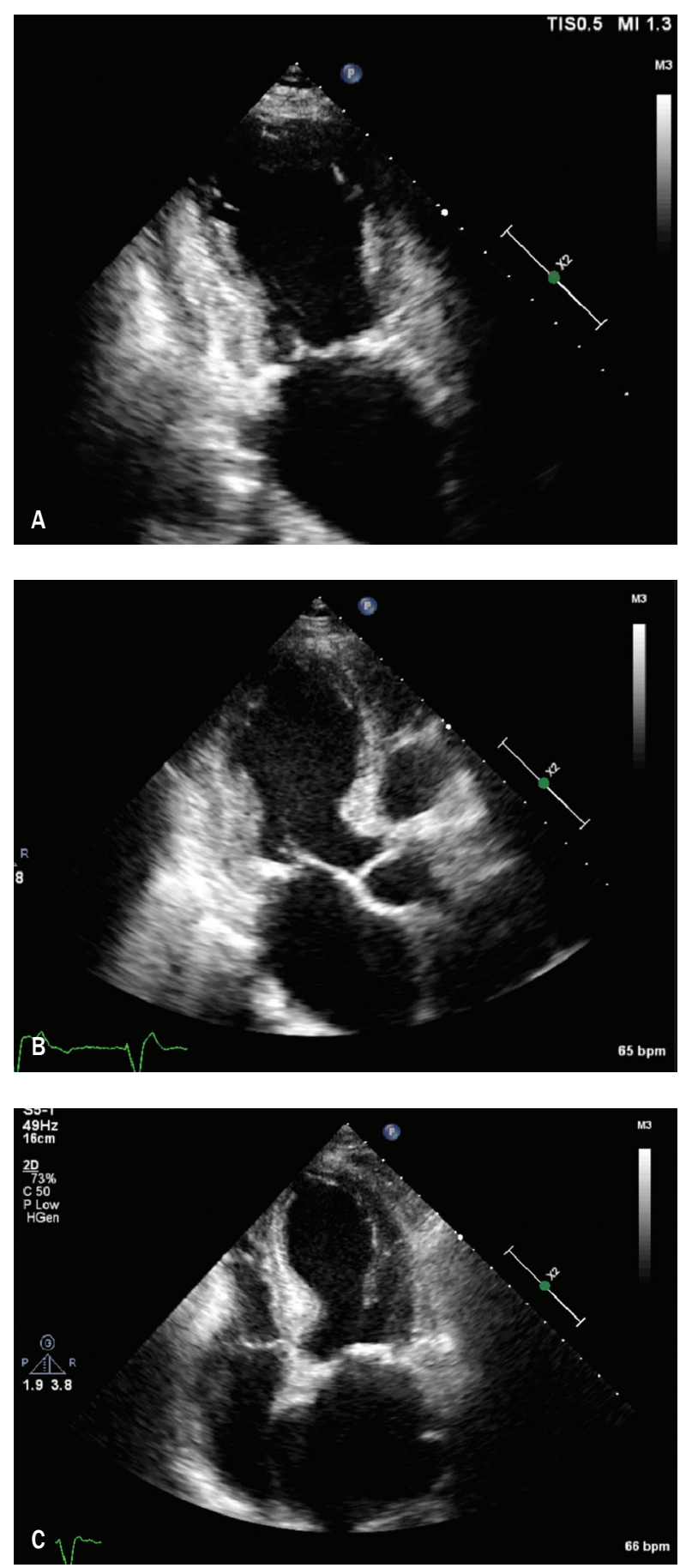

Rycina 1A-C. Badanie echokardiograficzne u pacjentki z kardiomiopatią takotsubo wykonane w dniu przyjęcia do szpitala

przyjęciu do szpitala i często powtarzanego w trakcie hospitalizacji oraz w trakcie ambulatoryjnych badań kontrolnych są niezbędne do potwierdzenia lub wykluczenia diagnozy (ryc. 1, 2). Autor zwraca również uwagę na potrzebę zwiększenia „czujności” lekarzy w wykrywaniu TCM. Dotyczy to pacjentów zgłaszających się do lekarza z powodu dławicy piersiowej, duszności, kołatania serca lub innych, często nietypowych, objawów (tab. 5) [8]. 


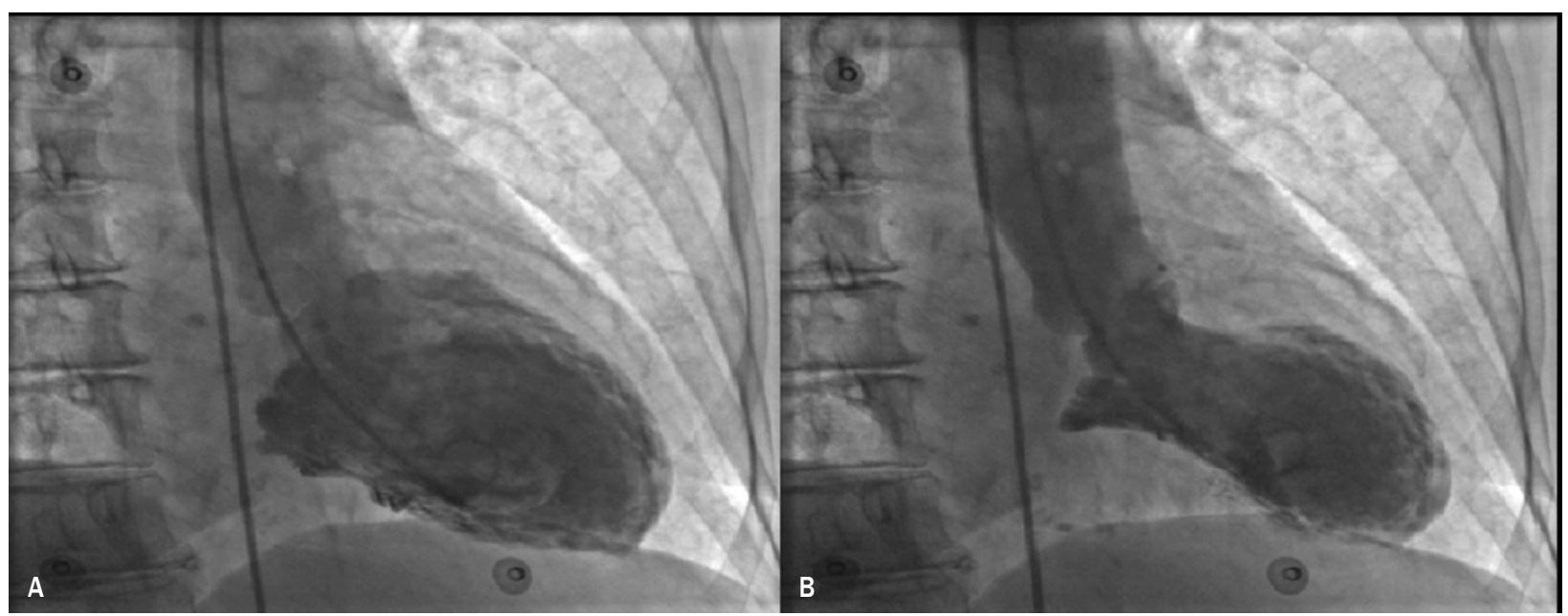

Rycina 2A, B. Wentrykulografia wykonana u pacjentki z kardiomiopatią takotsubo

Tabela 5. Kryteria rozpoznawania kardiomiopatii takotsubo (TCM, takotsubo cardiomyopathy) zaproponowane w 2014 roku (na podstawie [8])

Przemijająca hipokineza/akineza/dyskineza segmentów lewej lub prawej komory, zwykle u kobiet po menopauzie często, ale nie zawsze, związana ze stresującym wydarzeniem (emocjonalnym lub fizycznym), o którym pacjent poinformował lekarza

Wykluczenie innych patologii (np. niedokrwienia, zapalenia mięśnia sercowego, toksycznego uszkodzenia, tachykardii, które mogą bardziej wiarygodnie wyjaśnić pojawienie się zaburzeń kurczliwości

Mogą występować łagodne postaci TCM charakteryzujące się przemijającą hipokinezą, akinezą lub dyskinezą segmentów lewej lub prawej komory i/lub odwróceniem załamków T i wydłużeniem QT w trakcie obserwacji

TCM może współwystępować z innymi chorobami (włączając ostry zespół wieńcowy) - może być przez nie wywołana lub wywołać te choroby

\section{Zmiany w zapisie EKG}

Najbardziej powszechnymi odchyleniami w badaniu EKG stwierdzanymi przy przyjęciu u pacjentów z TCM są uniesienie odcinka ST (49-90\%), odwrócenie załamków T (44-83\%) oraz obecność załamków Q (27-32\%) [2, 9]. Podobny odsetek poszczególnych zmian w EKG jest opisywany w populacji polskiej [10]. Na podstawie analizy zapisów EKG wykonywanych codziennie w trakcie hospitalizacji, a następnie co miesiąc - aż do momentu normalizacji zapisu - opisano 4 fazy ewolucji EKG: 1) szybkie uniesienie odcinka ST, 2) pierwszy szczyt ujemnych załamków T w 1.-3. dniu, 3) przejściowe odwrócenie ujemnych załamków T w 2.-6. dniu, 4) rozwój dużych, odwróconych załamków T z wydłużeniem odstępu QT, utrzymujące się do 2 miesięcy od wyzdrowienia [11]. Uniesienie odcinka
ST częściej obserwuje się na początku objawów. Według Tsuchihashi [9] częstość występowania uniesienia odcinka ST wynosi 90\%, jeżeli EKG zostanie wykonane w czasie $6 \pm$ 9 h od początku objawów. Uniesienie odcinka ST częściej występuje w odprowadzeniach przedsercowych V3-V6 [9]. Patologiczne załamki Q są obecne u $42 \%$ pacjentów z TCM, częściej w odprowadzeniach V4-V6 [12]. Zanikanie załamków Q i pojawianie się załamków R opisano w 75\% przypadków i jest najprawdopodobniej elektrofizjologicznym odzwierciedleniem ogłuszenia lub obrzęku mięśnia sercowego [13]. Odwrócenie załamków T zwykle pojawia się w ciągu pierwszych 24-72 h od początku wystąpienia objawów i jest obecne w wielu odprowadzeniach [11, 14] - najczęściej V2-V6, ale również I, II i aVL. Liczba odprowadzeń z ujemnymi załamkami T jest zazwyczaj większa u pacjentów z TCM niż u osób z zawałem serca z uniesieniem odcinka ST (STEMI, ST-segment elevation myocardial infarction) $[11,14,15]$. Wydłużenie odstępu QT jest związane z początkiem pojawienia się ujemnych załamków T i bardziej wyraźne u pacjentów z TCM niż ze STEMI. W ostatnim czasie opisano obniżenie woltażu zespołów QRS u pacjentów z TCM, które ma prawdopodobnie związek z obrzękiem mięśnia sercowego [16]. Niski woltaż w EKG wykonanym przy przyjęciu lub atenuację woltażu w trakcie hospitalizacji obserwowano u 91\% i 93\% pacjentów [17]. Wielu autorów próbowało wyznaczyć kryteria elektrokardiograficzne umożliwiające rozróżnienie TCM i STEMI. Zebrano je w tabeli 6.

\section{Biomarkery}

Charakterystyczną cechą TCM jest relatywnie niewielki wzrost stężeń kinazy kreatyny i troponiny w stosunku do rozległości zaburzeń kurczliwości [22]. Osoczowe stężenia katecholamin (adrenalina, noradrenalina, dopamina), neuropeptydu Y i serotoniny są podwyższone. U pacjentów 
Tabela 6. Kryteria różnicujące kardiomiopatii takotsubo (TCM, takotsubo cardiomyopathy) od zawału serca ściany przedniej (na podstawie [18])

\begin{tabular}{|c|c|c|c|c|}
\hline $\begin{array}{l}\text { Piśmienni- } \\
\text { ctwo }\end{array}$ & $\begin{array}{c}\text { Liczba } \\
\text { pacjentów }\end{array}$ & Kryteria różnicujące TCM od zawału serca & $\begin{array}{l}\text { Czułość } \\
(\%)\end{array}$ & $\begin{array}{c}\text { Specyficznośc } \\
(\%)\end{array}$ \\
\hline \multirow{2}{*}{$\begin{array}{l}\text { Ogura } \\
\text { i wsp. [12] }\end{array}$} & $\mathrm{TCM}, \mathrm{n}=13$ & \multirow[t]{2}{*}{ Brak przeciwstawnych odchyleń w odprowadzeniach znad ściany dolnej } & \multirow[t]{2}{*}{100} & \multirow[t]{2}{*}{69} \\
\hline & STEM, $n=13$ & & & \\
\hline \multirow{3}{*}{$\begin{array}{l}\text { Bybee } \\
\text { i wsp. [19] }\end{array}$} & $\mathrm{TCM}, \mathrm{n}=18$ & Brak patologicznych załamków Q & 83 & 69 \\
\hline & \multirow[t]{2}{*}{ STEMI, $n=26$} & Suma uniesienia ST w V4-V6/suma uniesienia ST w V1-V3 $\geq 1$ & 80 & 77 \\
\hline & & Uniesienie ST w V2 $<1,75 \mathrm{~mm}$ i V3 $<2,5 \mathrm{~mm}$ & 67 & 94 \\
\hline \multirow{3}{*}{$\begin{array}{l}\text { Kosuge } \\
\text { i wsp. [20] }\end{array}$} & \multirow[t]{2}{*}{$\mathrm{TCM}, \mathrm{n}=33$} & \multirow{2}{*}{$\begin{array}{l}(3 \times \text { uniesienie ST w V2) + (uniesienie ST w V3) + (2 × uniesienie ST w } \\
\text { V5) }<11,5 \mathrm{~mm}\end{array}$} & 94 & 72 \\
\hline & & & \multirow{2}{*}{97} & \multirow{2}{*}{75} \\
\hline & STEMI, $\mathrm{n}=342$ & Uniesienie ST w aVR (= obniżenie ST w aVR) > 0,5 mm & & \\
\hline \multirow{6}{*}{$\begin{array}{l}\text { Tamura } \\
\text { i wsp. [21] }\end{array}$} & TCM, $n=62$ & Brak uniesienia ST w V1 > 1,0 mm & 94 & 71 \\
\hline & \multirow[t]{5}{*}{ STEMI, $n=280$} & Obniżenie ST w aVR > 0,5 mm i brak uniesienia ST w V1 > 1,0 mm & 91 & 96 \\
\hline & & Uniesienie ST $\geq 1,0 \mathrm{~mm}$ w V3 bez uniesienia ST $\geq 1,0 \mathrm{~mm}$ w V1 & 68 & 81 \\
\hline & & Uniesienie ST $\geq 1,0 \mathrm{~mm}$ w V3 i/lub V4 bez uniesienia ST $\geq 1,0 \mathrm{~mm}$ w V1 & 73 & 81 \\
\hline & & $\begin{array}{l}\text { Uniesienie ST } \geq 1,0 \mathrm{~mm} \text { w } \geq 1 \text { odprowadzeniu V3-V5 bez uniesienia ST } \\
\geq 1,0 \mathrm{~mm} \text { w V1 }\end{array}$ & 74 & 81 \\
\hline & & $\begin{array}{l}\text { Uniesienie ST } \geq 1,0 \mathrm{~mm} \text { w } \geq 2 \text { odprowadzeniach przedsercowych bez } \\
\text { uniesienia ST } \geq 1,0 \mathrm{~mm} \text { w V1 }\end{array}$ & 69 & 80 \\
\hline
\end{tabular}

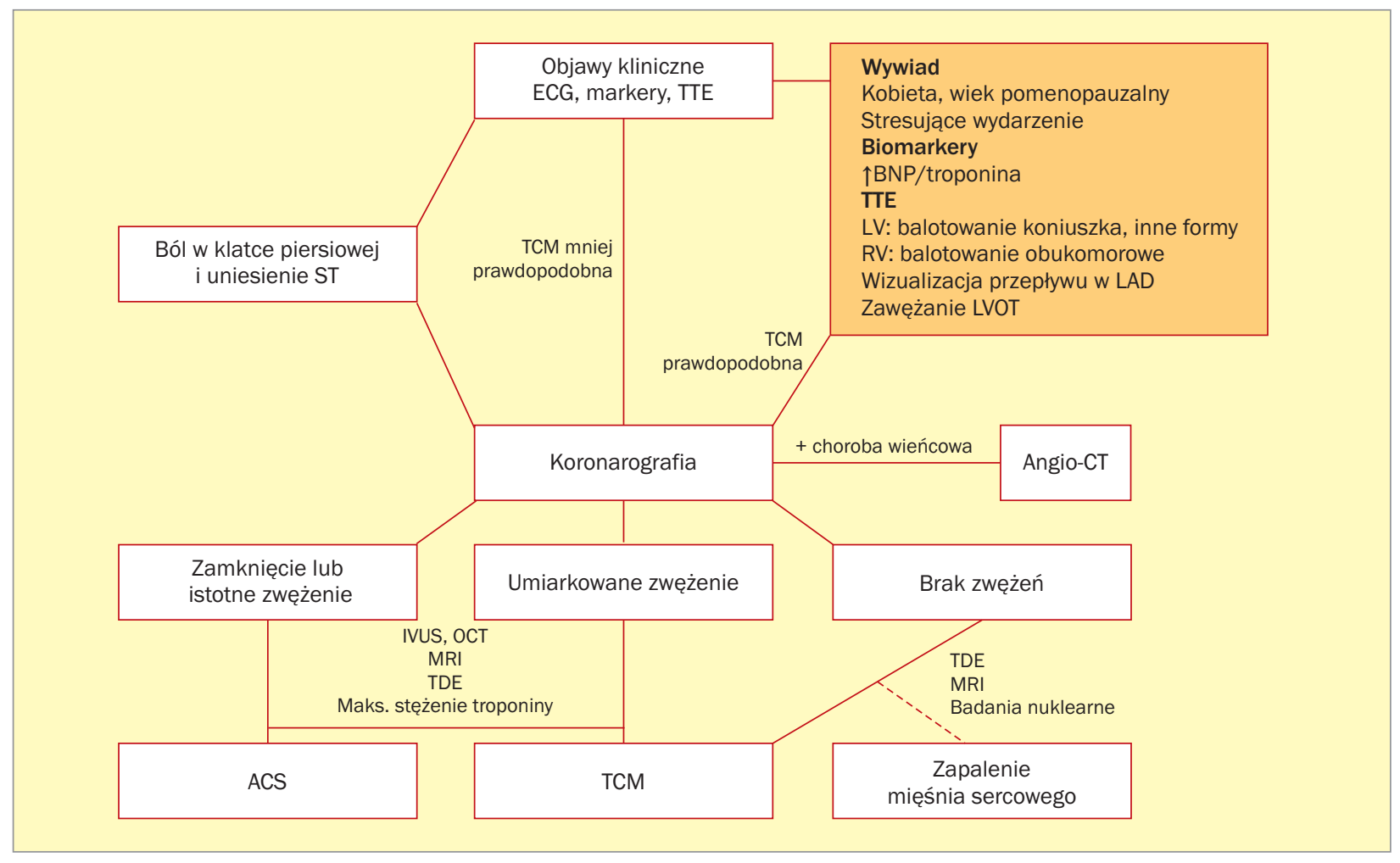

Rycina 3. Schemat diagnostyki kardiomiopatiii takotsubo (TCM, takotsubo cardiomyopathy) (na podstawie [27]); BNP (B-type natriuretic peptide) - peptyd natriuretyczny typu B; TTE (transthoracic echocardiography) - echokardiografia przezklatkowa; LV (left ventricle) - lewa komora; RV (right ventricle) - prawa komora; LAD (left anterior descending artery) - gałąź przednia zstępująca; LVOT (left ventricular outflow tract) - droga odpływu lewej komory; ECG (electrocardiography) - elektrokardiografia; angio-CT (computed tomography angiography) - angiografia metodą tomografii komputerowej; IVUS (intravascular ultrasound) - ultrasonografia wewnątrznaczyniowa; OCT (optical coherence tomography) - optyczna tomografia koherencyjna; MRI (magnetic resonance imaging) - rezonans magnetyczny; TDE (transthoracic Doppler echocardiography) - echokardiografia doplerowska; ACS (acute coronary syndrome) - ostry zespół wieńcowy 
z TCM w porównaniu z pacjentami z ACS w klasie III według Killipa stężenie katecholamin było 2-3 razy wyższe [23]. Jednak nie we wszystkich badaniach te obserwację potwierdzono. Stężenie peptydu natriuretycznego typu B (BNP, B-type natriuretic peptide) jest prawie zawsze podwyższone u pacjentów z TCM i wyższe niż u chorych ze STEMI [24]. Niektórzy autorzy uważają, że TCM można odróżnić od ACS na podstawie charakterystycznego profilu markerów sercowych, polegającego na nagłym wzroście stężenia N-terminalnego propeptydu natriuretycznego typu B (NT-proBNP, N-terminal pro brain natriuretic peptide) w ciągu kilku pierwszych dni przy tylko nieznacznym wzroście markerów martwicy miokardium (stosunek wartości NT-pro BNP/troponiny) [25].

Większość autorów uważa, że u wszystkich pacjentów zgłaszających do szpitala z uniesieniem odcinka ST w zapisie EKG powinno się wykonać pilną koronarografię w celu wykluczenia zawału serca [26]. Istnieją jednak publikacje, których autorzy proponują możliwość postawienia diagnozy
TCM na podstawie oznaczenia markerów sercowych i badań nieinwazyjnych. Pozwoliłoby to pominąć badanie inwazyjne, jakim jest koronarografia, u niektórych chorych. Proponowany schemat diagnostyczny przedstawiono na rycinie 3.

\section{Podsumowanie}

Na podstawie przedstawionych licznych schematów diagnostyki TCM widać, jak bardzo złożona jest to jednostka chorobowa i jak wiele niesie ze sobą niewiadomych. Kryteria rozpoznania nie są do końca ustalone, jednak w miarę pojawiania się kolejnych publikacji stają się coraz bardziej precyzyjne. Wydaje się, że w niektórych przypadkach - po dokładnej analizie wyników badań nieinwazyjnych - możliwe jest nawet odstąpienie od koronarografii.

\section{Konflikt interesów}

Autorki nie zgłaszają konfliktu interesów.

\section{Abstract}

Takotsubo cardiomyopathy (TCM) is a relatively recently described disease which mimics acute coronary syndrome. It occurs in 1-3\% of patients admitted to the hospital with a suspected myocardial infarction. The aetiology remains unknown. Patients with TCM have generally a good prognosis, with a rapid improvement of left ventricle systolic function within a few days or weeks. However, the complications sometimes occur and can even lead to death. It is important to distinguish from myocardial infarction on the early stage because despite similar symptoms the treatment and prognosis are different. Therefore, many researchers are trying to create the criteria to distinguish between these two diseases on symptoms onset.

Key words: takotsubo, apical ballooning syndrome, stress-induced cardiomyopathy

(Folia Cardiologica 2015; 10, 1: 58-64)

\section{Piśmiennictwo}

1. Bybee K.A., Kara T., Prasad A. i wsp. Systematic review: transient left ventricular apical ballooning: a syndrome that mimics ST-segment elevation myocardial infarction. Ann. Intern. Med. 2004; 141: 858-865.

2. Gianni M., Dentali F., Grandi A.M. i wsp. Apical ballooning syndrome or takotsubo cardiomyopathy: a systematic review. Eur. Heart J. 2006; 27: 1523-1529.

3. Dote K., Sato H., Tateishi H. i wsp. Myocardial stunning due to simultaneous multivessel coronary spasms: a review of 5 cases. J. Cardiol. 1991; 21: 203-214.

4. Prasad A., Lerman A., Rihal C.S. Apical ballooning syndrome (takotsubo or stress cardiomyopathy): a mimic of acute myocardial infarction. Am. Heart J. 2008; 155: 408-417.

5. Kawai S., Kitabatake A., Tomoike H.; Takotsubo Cardiomyopathy Group. Guidelines for diagnosis of takotsubo (ampulla) cardiomyopathy. Circ. J. 2007; 71: 990-992.

6. Wittstein I.S. Stress cardiomyopathy: a syndrome of catecholamine-mediated myocardial stunning? Cell. Mol. Neurobiol. 2012; 32: 847-857.
7. Redfors B., Shao Y., Omerovic E. Stress-induced cardiomyopathy (takotsubo) - broken heart and mind? Vasc. Health Risk. Manag. 2013; 9: 149-154.

8. Madias J. Why the current diagnostic criteria of Takotsubo syndrome are outmoded: a proposal for new criteria. Int. J. Cardiol. 2014; 174: 468-470.

9. Tsuchihashi K., Ueshima K., Uchida T. i wsp. Transient left ventricular apical ballooning without coronary artery stenosis: a novel heart syndrome mimicking acute myocardial infarction. Angina Pectoris-Myocardial Infarction Investigations in Japan. J. Am. Coll. Cardiol. 2001; 38: 11-18.

10. Opolski G., Pawlak M.M., Roik M.F. i wsp. Clinical presentation, treatment, and long-term outcomes in patients with takotsubo cardiomyopathy. Experience of a single cardiology center. Pol. Arch. Med. Wewn. 2010; 120: 231-236.

11. Mitsuma W., Kodama M., Ito M. Serial electrocardiographic findings in women with takotsubo cardiomyopathy. Am. J. Cardiol. 2007; 100: 106-109. 
12. Ogura R., Hiasa Y., Takahashi T. i wsp. Specific findings of the standard 12-lead ECG in patients with takotsubo cardiomyopathy: comparison with the findings of acute anterior myocardial infarction. Circ. J. 2003; 67: 687-690.

13. Sharkey S.W. Electrocardiogram mimics of acute ST-segment elevation myocardial infarction: insights from cardiac magnetic resonance imaging in patients with takotsubo (stress) cardiomyopathy. J. Electrocardiol. 2008; 41: 621-625.

14. Guerra F., Rapaj E., Pongetti G. i wsp. Differences and similarities of repolarization patterns during hospitalization for takotsubo cardiomyopathy and acute coronary syndrome. Am. J. Cardiol. 2013; 112: 1720-1724.

15. Kurisu S., Inoue I., Kawagoe T. i wsp. Time course of electrocardiographic changes in patients with tako-tsubo syndrome: Comparison with acute myocardial infarction with minimal enzymatic release. Circ. J. 2004; 68: 77-81.

16. Madias J.E., Bazaz R., Agarwal H. i wsp. Anasarca-mediated attenuation of the amplitude of electrocardiogram complexes: a description of a heretofore unrecognized phenomenon. J. Am. Coll. Cardiol. 2001; 3: 756-764.

17. Madias J.E. Transient attenuation of the amplitude of the QRS complexes in the diagnosis of takotsubo syndrome. Eur. Heart J. Acute Cardiovasc. Care 2014; 3: 28-36.

18. Kosuge M., Kimura K. Electrocardiographic findings of takotsubo cardiomyopathy as compared with those of anterior acute myocardial infarction. J. Electrocardiol. 2014; 47: 684-689.

19. Bybee K.A., Motiei A., Syed I.S. i wsp. Electrocardiography cannot reliably differentiate transient left ventricular apical ballooning syndrome from anterior ST-segment elevation myocardial infarction. J. Electrocardiol. 2007; 40: 38.e1-e6.
20. Kosuge M., Ebina T., Hibi K. i wsp. Simple and accurate electrocardiographic criteria to differentiate takotsubo cardiomyopathy from anterior acute myocardial infarction. J. Am. Coll. Cardiol. 2010; 55: 2514-2516.

21. Tamura A., Watanabe T., Ishihara M. i wsp. A new electrocardiographic criterion to differentiate between takotsubo cardiomyopathy and anterior wall ST-segment elevation acute myocardial infarction. Am. J. Cardiol. 2011; 108: 630-633.

22. Pilgrim T.M., Wyss T.R. Takotsubo cardiomyopathy or transient left ventricular apical ballooning syndrome: a systematic review. Int. J. Cardiol. 2008; 124: 283-292.

23. Wittstein I.S., Thiemann D.R., Lima J.A. i wsp. Neurohumoral features of myocardial stunning due to sudden emotional stress. N. Engl. J. Med. 2005; 352: 539-548.

24. Ahmed K.A., Madhavan M., Prasad A. Brain natriuretic peptide in apical ballooning syndrome (takotsubo/stress cardiomyopathy): comparison with acute myocardial infarction. Coron. Artery Dis. 2012; 23: 259-264.

25. Frohlich G.M., Schoch B., Schmid F. i wsp. Takotsubo cardiomyopathy has a unique cardiac biomarker profile: NT-proBNP/myoglobin and NT-proBNP/troponin T ratios for the differential diagnosis of acute coronary syndromes and stress induced cardiomyopathy. Int. J. Cardiol. 2012; 154: 328-332.

26. Duran-Cambra A., Sutil-Vega M., Fiol M. i wsp. Systematic review of the electrocardiographic changes in the takotsubo syndrome. Ann. Noninvasive Electrocardiol. 2015; 20: 1-6.

27. Bossone E., Lyon A., Citro R. i wsp. Takotsubo cardiomyopathy: an integrated multi-imaging approach. Eur. Heart J. Cardiovasc. Imaging 2014; 15: 366-377. doi: 10.1093/ehjci/jet167. 